\title{
IN VITRO ДАХЬ ЭЛЭГНИЙ ХАВДАРЫН ЭСИЙН ҮЙЛ АЖИЛЛАГААНД НАРИЙН ИШТ ЮНГИ (YOUNGIA TENUICAULIS ВАВC. ЕT) УРГАМЛЫН ЗАРИМ ХАНДНЫ УЗУУЛЭХ НӨЛӨӨ
}

\author{
Г. Номинтуяа ${ }^{1}$, Г. Одонтуяа ${ }^{2}$, Ц. Оюунсүрэн ${ }^{1}$ \\ ${ }^{1}$ ШУА-ийн Биологийн хүрээлэнгийн Молекул биологийн лаборатори
} ${ }^{2}$ ШУА-ийн Хими хими-технологийн хүрээлэнгийн Байгалийн нэгдлийн химийн лаборатори Nomi1988@yahoo.de

\section{Хураангуй}

Уламжлалт анагаах ухаанд өргөнөөр хэрэглэгдэж ирсэн Нарийн ишт юнги (Youngia tenuicaulis Babc. et Stebbings Czer., Compositae) ургамлын элэгний хавдарын эсийн өсгөврийн үйл ажиллагаанд үзүүлэх нөлөөллийг судлах зорилгоор эсийн хуваагдлыг дарангуйлах идэвхи өндөртэй байж болох уг ургамлын газрын дээд хэсэг, мөн үндэснээс бэлтгэсэн дихлорметан ба этанолон хандыг ашиглан эсийн болон молекул биологийн аргуудаар судлагаа хийв.

Бидний судалгааны үр дүнд газрын дээд хэсгийн дихлорметан ханд нь in vitro дахь элэгний хавдарын эсийн хуваагдалд сөргөөр нөлөөлж, шилжин ургах чадварыг $86.6 \%$-иар бууруулж, ZPYVE1 болон GPR175 зэрэг генүүдийн экспрессийг дарангуйлж байв.

Youngia tenuicaulis ургамлын газрын дээд хэсгийн дихлорметанханд нь эсийн фокал адхейшн сайт үүсэлтийг саатуулах замаар уг хавдарын эсийн хоруу болон метастатик шинж чанарыг бууруулж байв.

ТҮлхүур үг: Youngia tenuicaulis, хавдарын эс, эсийн хуваагдал, генийн экспресс

\section{ОРШИЛ}

Манай улсад сүүлийн 20 жилд хорт хавдараар өвдөгсөдийн тоо ойролцоогоор 2 дахин нэмэгдсэн [1, 2, 3] ба ДЭМБын мэдээгээр 2013 оны байдлаар манай улс элэгний хорт хавдарын тохиолдлоор дэлхийд тэргүүлэх байр эзлэх болов. Элэгний хорт хавдар буюу анхдагч өмөн нь вирусын халдвар, хүний удамшил, дархлааны болон гадаад орчны төрөл бүрийн хүчин зүйлсийн нөлөөгөөр үүсдэг тул уг өвчин үүсэх нөхцөл, ҮзҮҮлэх хоруу чанар нь бүс нутаг бүрт харилцан адилгүй байдаг. Тухайлбал Ази, Африкийн орнуудад гепатит В, С вирусуудын халдвар, афлатоксин мэтийн гадны хүчин зүйлс түлхүҮ үүрэгтэй байдаг. Дээрх гадны хүчин зүйлүүд эсийн хуваагдлыг хянаж байдаг чухал үүрэгтэй генүүдийн үйл ажиллагааг шууд болон шууд бусаар өөрчлөх замаар хавдар үүсгэх нөхцөлийг бий болгодог.

Орчин үед хавдарын эсийг in vitro буюу тохиромжтой орчин, нөхцөлд тогтвортой өсгөвөрлөж, хавдарын эсийн өсөлтийн зүй тогтол, эс хоорондын харилцан үйлчлэл зэрэг хавдарын эсийн онцлогуудыг судалж, мөн хавдарын эсүүдэд химийн болон биологийн гаралтай бэлдмэлүүдийн үйлчлэлийг түлхүҮ судалдаг болжээ.

Тиймээс Нарийн ишт юнги (Youngia tenuicaulis Babc. et Stebbings Czer., Compositae) ургамлын хандны элэгний хавдарын анхдагч эсийн өсгөвөрт нөлөөлөх 
байдлыг эсийн болоод молекул биологийн арга зүй ашиглан тогтооход энэхүҮ судалгааны ажлын зорилго оршив.

\section{СУДАЛГААНЫ МАТЕРИАЛ БА АРГА ЗУЙ}

Ургамлын цуглуулга, дээж бэлтгэх: Нарийн ишт юнги (Y. tenuicaulis) ургамлын газрын дээд хэсэг ба үндсийг 2010 оны 8 сарын эхэнд Архангай аймгийн Ихтамир сумын нутгаас түүж, хатаан, жижиглэж биологийн судалгаанд бэлтгэв. Энэ ургамлын зүйлийн тодорхойлолтыг ШУА-ийн Ботаникийн хүрээлэнгийн эрдэм шинжилгээний тэргүүлэх ажилтан, ангилал зүйч, доктор, профессор Ч.Санчир хийсэн ба хандны дээжийг Хими, химитехнологийн хүрээлэнд бэлтгэсэн.

Ургамлаас ханд гарган авах: Нарийн ишт юнгийн газрын дээд хэсэг ба үндэсний жижиглэсэн дээжийг 80 \% этилийн спиртээр мацерацийн аргаар хандланшүүж, вакуум ууршуулагчаар өтгөрүүлсэн ба өтгөн хандыг нэгтгэн газрын дээд хэсгийн, үндэсний хандуудыг тус тус гарган авсан. Эдгээрийг дихлорметан, этилацетат, н-бутанолоор тус тус бүлэглэн хандалж, дахин өтгөрүүлэн хэрэгцээт хандуудыг бэлтгэсэн.

Эсийн хуваагдлын шинжилгээ $[4,5]$ : Бид манай Молекул Биологийн лабораторид гарган авсан элэгний хавдарын анхдагч эсийн (РСС) өсгөврийг энэХүу судалгаанд ашигласан. Эсийн хуваагдлын шинжилээг хандаар үйлчилсэний дараа эсийг тоолох ба эс дэхь митохондрийн редуктаза энзимийн идэвхийг тодорхойлох гэсэн 2 аргаар хийж гүйцэтгэв. Эсээс $0.5 \times 10^{5}$ эс/мл эс тооцон авч 24 нүхтэй хавтанд 5\% $\mathrm{CO}_{2}$, $37^{\circ} \mathrm{C}$-д өсгөвөрлөв. RPMI-1640 тэжээлийн орчинд байх DMSO-д уусгасан ургамлын хандуудын эцсийн концентрацийг 50 мкг/ мл, 100 мкг/мл, 250 мкг/мл, 500 мкг/мл байхаар тооцон 24 цаг эсэд үйлчлүүлсэн. Трипсинийг ашиглан эсүүдийг салгаж, эсийн суспензи Үүсгэн, эсийн тоог Neubauer-ийн тор ашиглаж гаргасан.

Эсийн морфологид ҮзҮүлэх нөлөөг тогтоох [6]: $0.5 \times 10^{5}$ эс/мл тооны эсүүдийг
24 нүхтэй эсийн өсгөвөрийн хавтанд 24 цаг өсгөвөрлөсөний дараа тэжээлийн орчинд 100 мкг/мл ханд хийж дахин өсгөвөрлөн 24 цагийн дараа зураг авав. Хяналтын болон хандаар үйлчилсэн эсүүдийн морфологийн өөрчлөлтийг харьцуулав.

Эсийн шилжин ургах чадварын шинжилгээ [7]: Эсийн шилжин ургах хурдад 4 хандны үзүүлэх байдлыг судлахын тулд 100 мкг/мл концентраци бүхий хандаар үйлчилсэн болон хяналтын эсийн нэг давхаргад шарх үүсгэв. Шарх үүсгэсэнээс хойш 30 минут болон 24, 48, 72 цагийн дараaх эсийн ургалтын байдлыг TsView программ ашиглан, микроскопоор зураг авч хэмжилт хийж эсийн шилжин хөлдөх чадварыг тооцоолов.

Апоптозийн шинжилгээ [8]: Апоптозийн процессын сүүлийн шатанд апоптотик энзимүүд эсийн макромолекулуудыг жижиг хэсгүүд болгож задалдаг тул бид ДНХ-ийн задралын байдлыг судласан. Эсийг 21 х $10^{5}$ эс/мл байхаар 24 цаг өсгөвөрлөсөний дараа 100 мкг/мл хандаар үйлчлэж 48 цаг туршилтын болон хяналтын эсүүдээс геномын ДНХийг ялгав. 0,8\%-ийн агарозын гельд электрофорез явуулж ДНХ-ийн задрал үүссэн байдлыг гель ба түүний зурагт тодорхойлсон.

Генийн экспрессийн шинжилгээ [9]: Хавдарын эсүүдийг 100 мкг/мл хандаар 24 цаг үйлчилсэний дараагаар нийт РНХ-ийг ялгасан. Комлементар ДНХ нийлэгжүүлж BCL2, GPR175, ZPYVE1 болон GAPDH генүүдийн экспрессийг илрүүлэхэд холбогдох праймерууд бүхий ПГУ-ын аргыг ашигласан.

Статистик шинжилгээ: Стандарт хазайлтыг EXCEL(Office program 2013) дээр SDEVA-аap тодорхойлсон бол $P$-ийн утгыг Student-ийн t-шалгуураар тодорхойлов. 


\section{СУДАЛГААНЫ ҮР ДҮН БА ХЭЛЦЭМЖ}

\section{Эсийн хуваагдалд нөлөөлсөн байдал}

Угургамлын газрын дээд хэсгийн дихлорметан болон үндэсний этанол, дихлорметаны ханд in vitro дахь элэгний хавдарын эсийн хуваагдлыг концентрациас хамааран хүчтэй дарангуйлах бөгөөд газрын дээд хэсгийн этанолын хандны хавдарын эсэд үзүүлэх нөлөө нь бусад хандуудтай харьцуулахад идэвхи багатай болох нь ажиглагдав (1-р зураг).
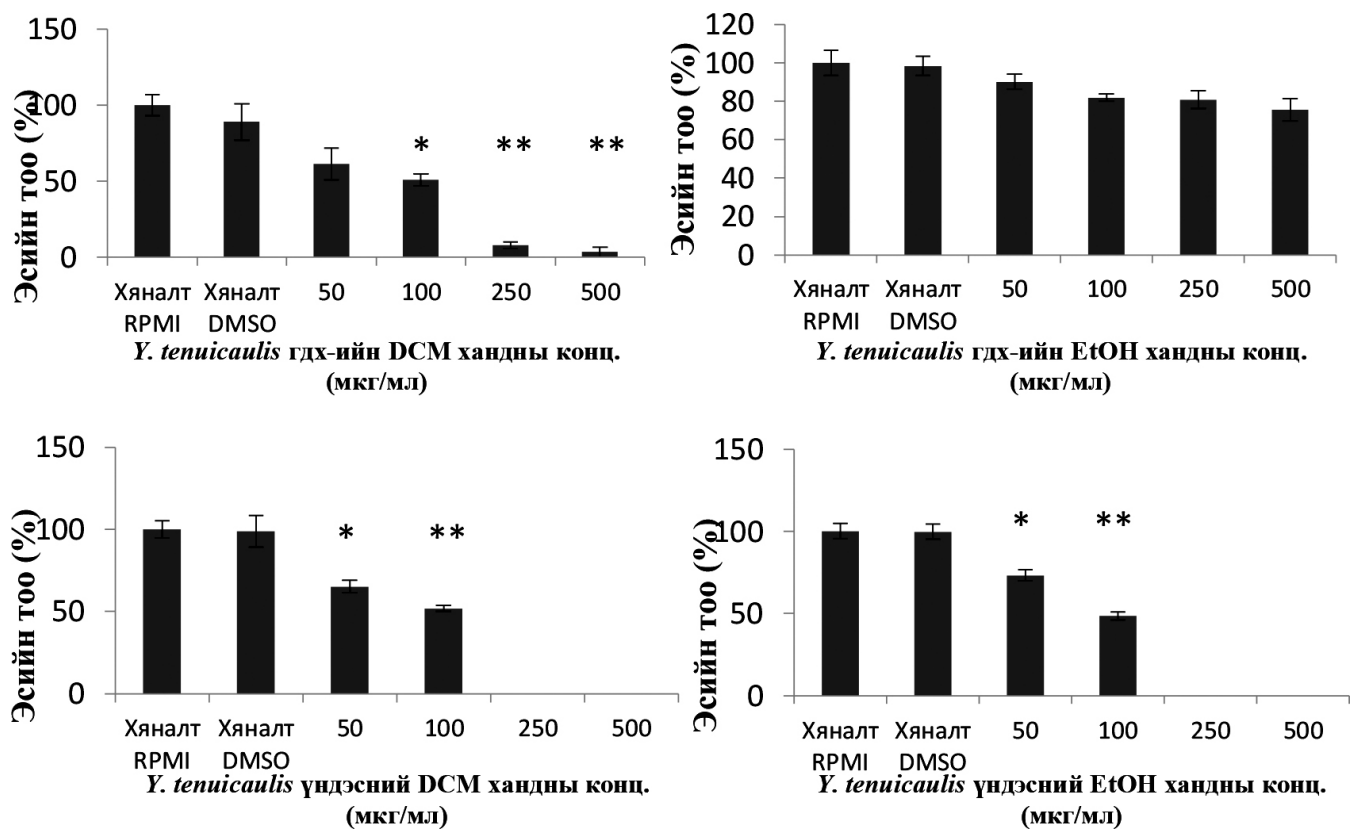

1-p зураг.Y. tепиісаиlis ургамльын 4 төрлийн хандаар үйлчилсэн болон үйлчлээгүй эсүҮдийн ургалтыьн идэвхийн өөрчлөлтийг харуулсан диаграмм. Босоо тэнхлэгт: амьд эсийн тоо, хэвтээ тэнхлэгт: кониентрацийг харуулав. ${ }^{*} P<0.05$, ${ }^{*} P<0.01$ утгыг Student-ийн $t$-шалгуураар тодорхойлов.

Эсийг шууд тоолох аргаас гадна ургамлын хандны эсийн митохондрийн редуктаза энзимийн идэвхид хэрхэн нөлөөлж буйг тогтоохын тулд ханд тус бүрийг 50 мкг/мл, 100 мкг/мл, 250 мкг/ мл, 500 мкг/мл концентрациар үйлчлэн, митохондрийн редуктаза энзимийн идэвхийн хэмжээг 450 нм-ийн гэрлийн шингээлтээр, хандаaр үйлчлээгүй хяналтийн эсийнхтэй харьцуулан шинжлэв. Судалгааны дүнд газрын дээд хэсгийн дихлорметан болон үндэсний этанол, дихлорметаны хандаар үйлчилсэн эсийн энзимийн идэвх концентрациас хамааран буурч байв (2-р зураг). 


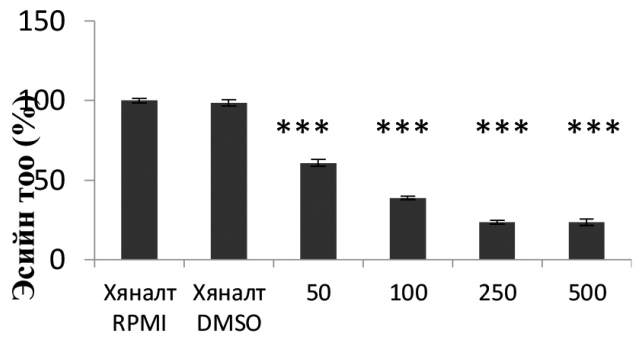

\section{Y. tenuicaulis гдх-ийн DCM хандны конц. (мкг/мл)}

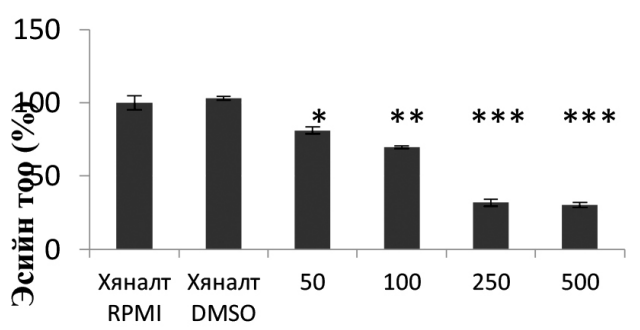

Y. tenuicaulis үндэсний DCM хандны конц. (мкг/мл)

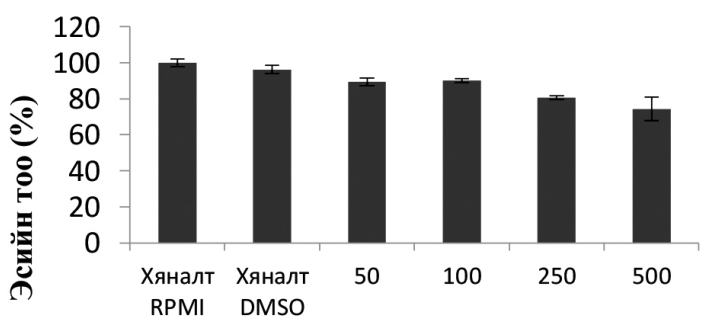

Y. tenuicaulis гдх-ийн ЕtОН хандны конц. (Мкг/мл)

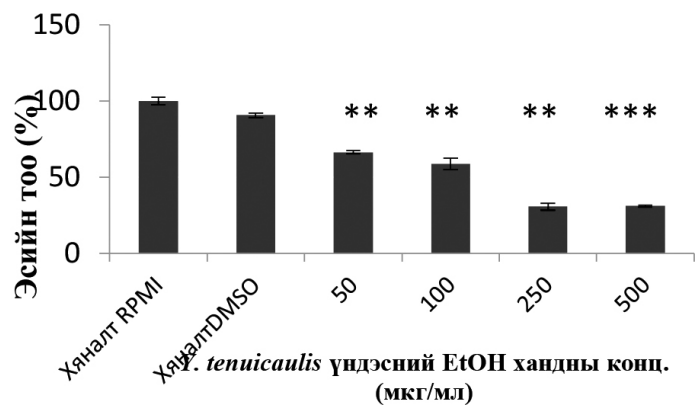

2-p зураг.Y. tепиicaulis ургамльнн 4 төрлийн хандаар үйлчилсэн болон үйлчлээгүй эсүҮдийн митохондрийн редуктаза энзимийн идэвхийн өөрчлөлтийг харуулсан диаграмм. Босоо тэнхлэгт: гэрлийн шингээлтийн идэвхи (амьд эсийн агууламжсаар), хэвтээ тэнхлэгт:хандны концентрацийг

харуулав. ${ }^{*} P<0.05, * * P<0.01, * * * P<0.001$ утгыг Student-ийн t-шалгуураар тодорхойлов.

In vitro дахь элэгний хавдарын эсийн морфологийн өөрчлөлт

Эсийг 100 мкг/мл концентраци бүхий газрын дээд болон үндэсний хэсгийн дихлорметан болон этанолон хандтай тэжээлийн орчинд 24 цагийн турш өсгөвөрлөхөд концентрациас хамааран эсийн морфологийн өөрчлөлтүҮд Үүсч байв. Микроскопийн энгийн ажиглалтаар харагдах хамгийн гол морфологийн өөрчлөлт нь эсүүдийн цитоплазмд үүсэх хөөсөнцөр цэврүүнүүд, (vesicle, vacoule) юм. Хандаар үйлчилсэн эсүүдэд жижиг хэмжээтэй олон тооны барзгар цэврүүнүүд үүсч цаашид улам томорч, том хэмжээний вакоульнууд бий болж, улмаар эсүүд задралд орсон байв (3-p зураг).
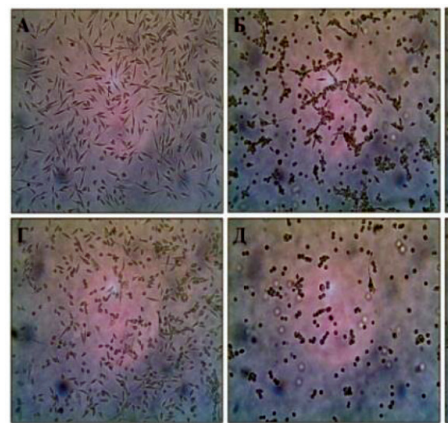

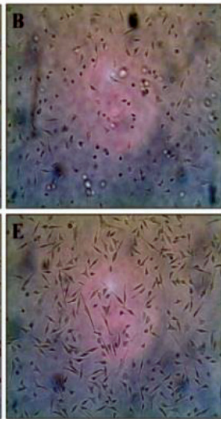

3-p зураг. Этанолон ба ДХМ хандаар үйлчилсэн эсүүдэд УҮссэн морфологийн өөрчлөлт. А: Хандаар үйлчлээгүй хяналтын эсүүд, Б: гдх-ийн ДХМ (100 мкг/мл), В: үндэсний ДХМ (100 мка) мл), Г: гдх-ийн этанол (100 мкг/мл), Д: үндэсний этанол (100мкг/мл), E: 0.01\% DMSO-той контрол эсҮҮд Микроскопийн обьективын өсгөлт: $10 X$ Энэ нь Y. tenuicaulis ургамлын газрын дээд хэсгийн дихлорметан болон үндэсний дихлорметан, этанол ханд нь элэгний хавдарын РСС эсийн ургалтыл дарангуйлах үйлчилгээтэй байж болохыг харуулна. 


\section{Эсийн шилжин хөдлөх чадварт}

нөлөөлсөн байдал

Элэгний хавдарын in vitro дахь хавдарын эсийн шилжин хөдлөх хурдад нөлөөлөх байдлыг судлахын тулд эсийн нэг үед авхаргад үүсгэсэн шархны эдгэх хурдыг хэмжихэд газрын дээд хэсгийн дихлорметаны хандаар үйлчилсэн эсүүдийн шилжин хөдлөх хурд нь үйлчлээгүй эсүүдийн шилжин хөдлөх хурдаас 86.6\%иар, үндэсний дихлорметаны ханд 80.88\%иар, үндэсний этанолон ханд 90.6\%-иар тус тус буурсан болох нь ажиглагдав. Харин газрын дээд хэсгийн этанолон ханд нь шилжин ургалтын хурдыг бууруулсангүй (4 ба 5-р зураг)

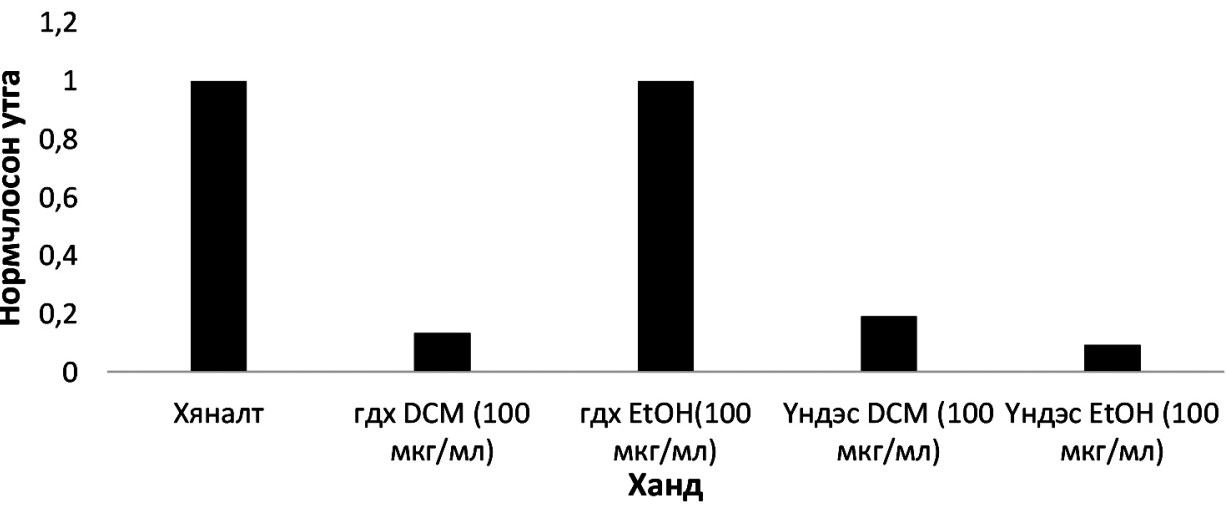

4-p зураг.Y. tenuicaulis 4 төрлийн хандаар үйлчилсэн (100 мкг/мл) болон үйлчлээгүй (Хяналт) эсүҮдийншилжин хөдлөх хурдыг харьиуулсан диаграмм. Босоо тэнхлэгтхяналтын эсүҮдийндундаж хурдыг 1-д нормчлосон утгыг үзүүлэв.
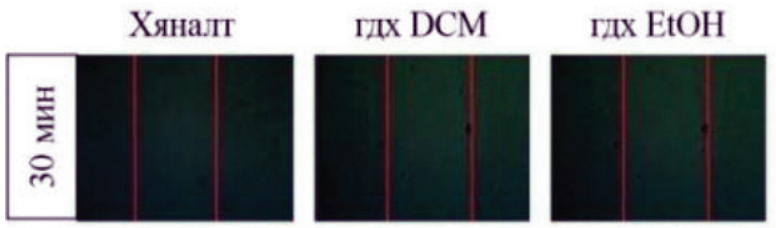

Үндэс DCM
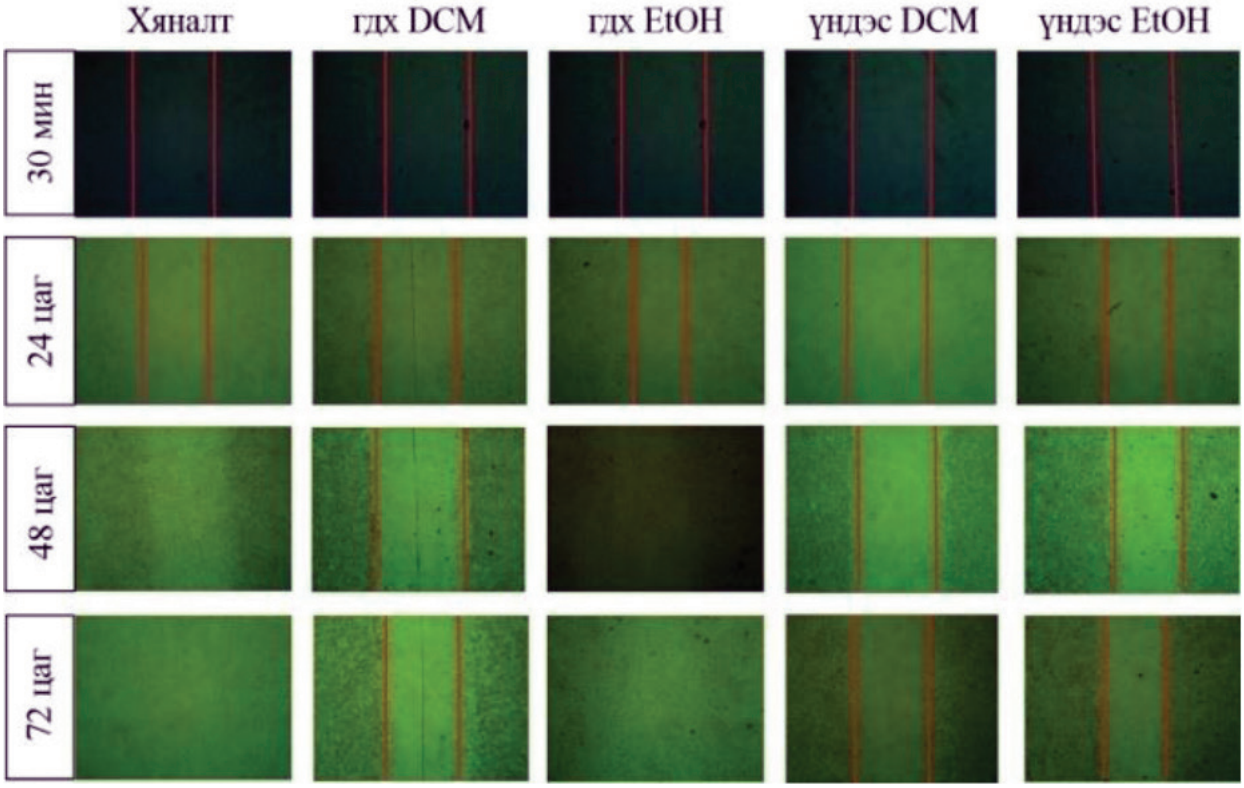

5-р зураг. Ойролиоогоор 90\%-ийн бүрхэлт (confluence) бүхий хандаар үйлчилсэн ба хандаар үйлчлээгүй эсийн нэг давхраанд шарх ҮҮсгэсэн улаанаар тэмдэглэсэнээс 30 минут болон 24, 48, 72 ияаций дараах байдал. Микроскопын обьективын өсгөлт: $4 X$. 


\section{ДНХ-ийн задралын байдал}

Хандууд хавдарын эсийн апоптозийн процессыг өдөөж буй эсэхийг шинжлэхэд юнги ургамлын 100 мкг/мл 3 төрлийн хандаар 48 цаг үйлчилсэн эсүүдээс ялгасан нийт ДНХ молекул задарсан байдал ажиглагдсангүй (6-р зураг).

6-p зураг.100 мкг/мл хандуудаар үйлчилсэн эсүүдээс ялгасан ДНХ-г 1\%-ийн агарозын гельд гүйлгэсэн зураг. М-маркер (1 кб), 1-хяналт, 2-гдх-н ДХМ ханд, 3-үндэсний ДХМ ханд, 4-үндэсний этанол ханд.

\section{Генүүдийн экспресст нөлөөлсөн байдал}

Y. tenuicaulis ургамлын газрын дээд ба үндэсний хэсгийн дихлорметаны болон үндэсний этанолон ханд нь элэгний хавдарын эсийн хуваагдал, шилжилт хөдөлгөөн зэрэгт нөлөөлж, эсийг үхүүлж байсан тулбид цаашид уг 3 хандны болон газрын дээд хэсгийн этанол хандны хавдарын эсэд үйлчлэх үйлчлэлийн молекул механизмыг тодорхойлохын тулд дээрх хандаар үйлчилсэн болон үйлчлээгүй эсийн генийн экспрессийг харьцуулан үзэв. Үүний тулд хавдарын үед эсэд ихээр идэвхждэг маркер болох ZPYVE1, мембраны транспортод үүрэгтэй GPR175,хавдар үүсэхэд үүрэгтэй BCL2 генүүдийн экспрессийн судлагааг хийсэн.

Ингэхэд газрын дээд ба үндэсний хэсгийн дихлорметан болон этанолон хандуудаар үйлчилсэн болон үйлчлээгүй эсүүдэд BCL2 генийн экспресс урвуу транскриптаза ПГУ-ын аргаар огт илэрсэнгүй.

Харин ZPYVE1, GPR175 генүүдийн

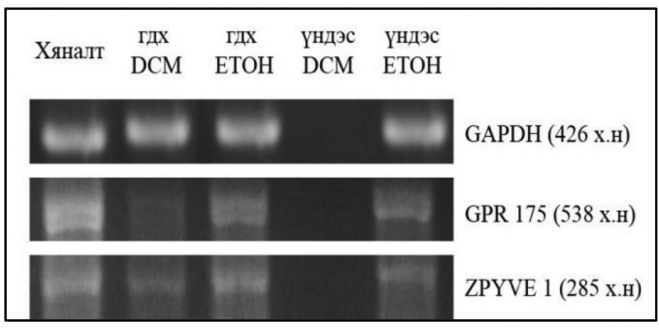

өндөр экспресс үйлчлээгүй эсэд илэрсэн бөгөөд газрын дээд хэсгийн дихлорметан ба үндэсний этанолон хандуудаар үйлчилсэн эсэд уг генийн экспресс буурч, үндэсний дихлорметан хандаар үйлчилсэн эсэд илрээгүй. Газрын дээд хэсгийн этанолон ханд нь бусад хандуудтай харьцуулахад эсийн хуваагдлын болон шилжин хөдлөх чадварын шинжилгээнүүдийн үр дүнтэй адил идэвхи багатай байна (7 ба 8-р зураг).

Энэхүу үр дүнгээс харахад уг хандны элэгний хавдарын РСС эсэд үүсгэж буй апоптозийн процесс нь BCL2 уургаaс үл хамаарсан апоптози эсвэл апоптози огт явагдахгүй байж магадгүй байна. Харин газрын дээд хэсгийн дихлорметаны хандаар үйлчилсэн эсэд ZPYVE1, GPR175 генийн хэмжээ эрс буурсан нь уг ханд эсийн Fak уургаар зохицуулагддаг актины полимержилтын үйл ажиллагаанд өөрчлөлт оруулж улмаар фокал адхейшн сайт үүсэлтийг саатуулах замаар хавдарын эсийн хоруу болон метастатик шинж чанарыг бууруулж байж болох юм.

7-p зураг. Хандаар үйлчилсэн (гдх-ийн DCM болон EtOH; үндэсний DCM болон ЕtОН) болон хандаар үйлчлээгүй (Хяналт) эсүУдийн ДНХ-ийн генийн экспрессийг гель элекртофорезийн аргаар ҮзүҮлсэн байдал. Баруун гар талд транскриптын нэр, урвуу транскриптаза ПГУ-ын бүтээгдэхүҮний хэмжэээг УзУҮлэв. 

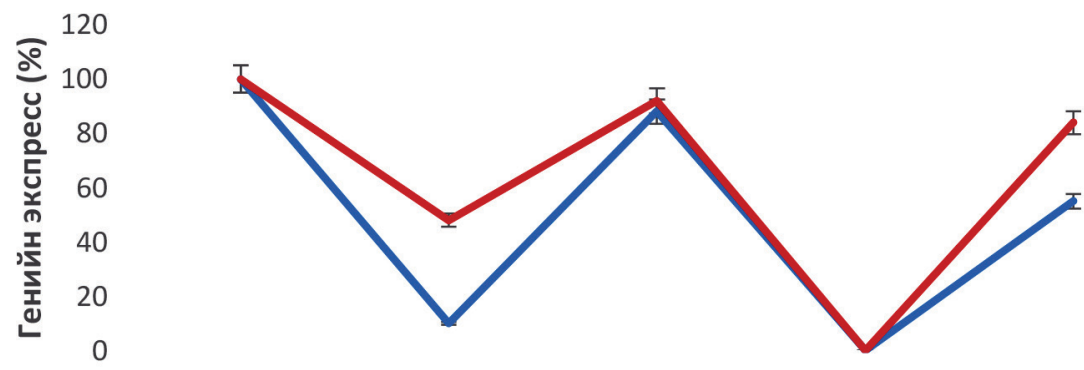

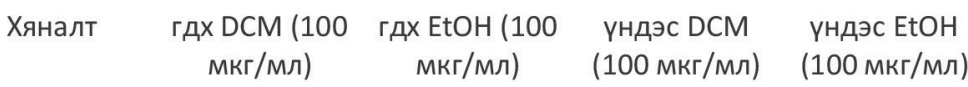

Ханд

\section{GPR175 ZPYVE1}

8-p зураг. Хандаар үйлчилсэн (гдх-ийн DCM болон ЕtОН; үндэсний DСМ болон ЕtОН) болон хандаар үйлчлээгүй (Хяналт) эсүҮд дээр урвуу транскриптаза ПГУ-аар хийсэн генийн экспрессийн иинжилгээний диаграмм. ПГУ-ын бүтээгдэхүҮнүҮдийн хэмжээг Image-J программаар тодорхойлсон ПГУ-ын бүтээгдэхүҮний хэмжээ заасан утгуудыг диаграммаар харуулав. ЭнэхүY диаграмм дээр хандаар үйлчлээгүй эсүүдийн ПГУ-ын бүтээгдхүүний хэмжээг 100\% гэж авч үзэв.

Бид судалгаандаa Youngia төрөлд хамаарах Y. tenuicaulis зүйлийн Нарийн ишт юнгийн дихлорметан, этанол, н-бутанол болон усан хандуудыг элэгний хавдарын PCC эс, түүний зарим шинж чанарт үзүүлэх нөлөөг шинжлэв. Урд өмнө нь уг зүйл ургамлын in vitro дахь хавдарын эсэд Үзүүлэх нөлөөг судалсан дүнгийн талаар хэвлэлийн материал олдсонгүй. Y. tenuicaulis нь гашуун амттай, сэрүүн чанартай, шар зэрэг өвчинд тустай гэж тэмдэглэсэн байдаг ба манай орны Хэнтий, Хангай, Монгол Алтай, Халх, Их нуруудын хотгор, Говь-Алтай орчмоор тархан ургасан байдаг $[10,11]$. Монгол оронд ургаж буй $Y$. tenuicaulis нь нэн ховор тохиолдох гамма-линолейний хүчил $(5.6 \%)$ болон бусад биологийн идэвхит ханаагүй тосны хүчлийн агууламжаараа өндөр [12]. Гаммалинолейний хүчил (омега-6 ханаагүй тосны хүчил) нь хүний эрүүл мэндэд ач тустай нэгдэл бөгөөд олон судлаачдын судалгааны үр дүнгээр хавдар, үрэвсэлт өвчин, хүний тархины үйл ажиллагаа болон төрөл бүрийн харшил зэрэгт эмчилгээний зорилгоор ашиглах боломжтойг нээжээ [13-19]. Харин бидний судалгаагаар $Y$. tenuicaulis ургамлын газрын дээд болон үндэсний хэсгийн 100 мкг/мл дихлорметан, үндэсний этанол хандууд нь хяналтын эстэй (100\%) харьцуулахад тус бүр 50.7\%, 52\%, $48.5 \%$ РСС эсийн хуваагдлыг саатуулах үйлчилгээтэй байсан бол газрын дээд хэсгийн 100 мкг/мл этанол ханд уг эсийн хуваагдлыг $81.9 \%$ бууруулсан. Хавдарын үсэрхийлэх шинж чанарыг in vitro нөхцөлд эсийн өсгөврийн шилжин ургах чадвараар төлөөлүүлэн судалдаг. Эсийн шилжин ургах нөхцлийг цитоскелет уургуудын нийлэгжилт нөхцөлдүүлдэг бөгөөд тодорхой хэсэгт төвлөрсөн трансмембраны уургууд тэдгээр уургуудтай медиатор уургуудаар дамжин холбогдож зохицуулдаг. Аливаа хавдарын эсийн туйлширсан цитоскелетийн полимержилтыг саатуулж хавдар үсэрхийлэх, шилжин ургах болон тархахыг зогсоох замаар хавдарыг эмчлэх боломжтой гэж үздэг. Бидний судалгаагаар PCC эсийн шилжин ургах чадварт $Y$. tenuicaulis ургамлын газрын дээд хэсгийн болон үндэсний дихлорметан ханд нь хяналттай харьцуулахад $86.6 \%, 80.8 \%$, үндэсний этанол ханд нь $90.6 \%$ тус тус саатуулах нөлөө үзүүлсэн бол уг ургамлын газрын дээд хэсгийн этанолон ханд нь үйлчилгээгүй. 
Шинжилгээний дүнд дээрх 4 төрлийн ханд нь хавдарын эсийн апоптозийн процессыг өдөөж, улмаар ДНХ-д задрал үүсгэсэн байдал илрээгүй. Мөн апоптози дарангуйлагч ген болох BCL2 болон трансмембраны GPR175, ZPYVE1 генүҮдийн экспрессийг урвуу транскриптаза ПГУ-ын аргаар шалгасан. Y. tenuicaulis-ийн газрын дээд хэсгийн дихлорметан хандаар үйлчилсэн РСС эсэд BCL2 генийн экспресс илрээгүй хэдий ч GPR175, ZPYVE1 генийн экспресс буурсан байв. Харин уг ургамлын үндэсний дихлорметан хандаар эсийг үйлчлэхэд дээрх 3 генийн экспресс ажиглагдсангүй. Эсийн апоптозийн үйл ажиллагаa bcl2 уургаас өөр уургаар дарангуйлагдсан байх боломжтой юм[20, 21].

Эдгээрээс үндэслэж нарийн ишт юнги (Youngia tenuicaulisBabc. et Stebbings Czer., Compositae) ургамлын газрын дээд болон үндэсний хэсгийн дихлорметан ба этанолон ханд нь элэгний хавдарын эсийн өсгөврийн хуваагдалыг бууруулж, эсийн шилжин хөдлөх хурдыг дарангуйлж байгаа ба газрын дээд хэсгийн дихлорметаны ханд нь бусад хандуудтай харьцуулахад ZPYVE1， GPR175 генийн экспрессийг бууруулж буй нь уг ханд эсийн Fak уургаap зохицуулагддаг актины полимержилтын процессд өөрчлөлт оруулж улмаар фокал адхейшн сайт үүсэхийг саатуулах замаар уг хавдарын эсийн хоруу болон метастатик шинж чанарыг бууруулж байж болох юм гэж үзэж байна. Эдгээр хандуудынүйлчлэл нь апоптозийн процессоос хамааралгүй, харин трансмембраны уургуудын генийн экспресстэй холбоотой байх магадлалтай.

\section{Ашигласан бүтээлийн жагсаалт}

1. http://www.cancerfreemongolia.mn/page/314.shtml?sel=725\&pid=722

2. http://www.wcrf.org/cancer_statistics/data_specific_cancers/liver_cancer_statistics.php

3. http://www.cancer-center.gov.mn/index.php? coid $=3 \&$ cid $=3$

4. Hughes D., and Mehmet H. (2003) Cell proliferation and apoptosis:18.

5. Tim M. (1983) Rapid colorimetric assay for cellular growth and survival: Application to proliferation and cytotoxicity assays. J Immun. Methods. (65): 55-63.

6. Da-ming Z., Molly B., Francisco G., Jean MF., Jian W., Roungyu Z., Huaguang L., and Changping Z. (2005)Cactus pear: a natural product in cancer chemoprevention. Nutrition J.(25):

7. Maria G.L. (1999) Cell Migration into a Wounded Area In Vitro. Methods in Mol.Biology (96): 177-82.

8. Wyllie A.H. (1980) Glucocorticoid-induced thymocyte apoptosis is associated with endogenous endonuclease activation. Nature 284(10): 555-6.

9. Freeman W M., Walker S J., and Vrana K E. (1999) Quantitative RT-PCR: pitfalls and potential. BioTechniques(26):112-22, 124-5.

10. Монгол орны ашигт ургамлын зурагт лавлах I 66р 2005 он.

11. Монголын гуурст ургамал таних бичиг В.И.Грубов $319 p 2008$ он.

12. Tsevegsuren N., Aitzetmuller K., and Vosmann K. (1999).Occurrence of gamma-linolenic acid in compositae: a study of Youngia tenuicaulis seed oil. Lipids. 34(5):525-9.

13. Attar-Bashi NM., Li D., and Sinclair AJ. (2004) Alpha-linolenic acid and the risk of prostate cancer. Lipids. 39(9):929-32.

14. Das UN. (2008) Essential fatty acids and their metabolites could function as endogenous $H M G-C o A$ reductase and ACE enzyme inhibitors, anti-arrhythmic, anti-hypertensive, antiatherosclerotic, anti-inflammatory, cytoprotective, and cardioprotective molecules. Review. Lipids Health Dis. Oct 15;7:37.

15. Kenny FS., Pinder SE., and Ellis IO. (2000) Gamma linolenic acid with tamoxifen as primary therapy in breast cancer. Int J Cancer. 85:643-648.

16. Kong X., Ge H., and Chen L. (2009) Gamma-linolenic acid modulates the response of multidrugresistant K562 leukemic cells to anticancer drugs. Toxicol In Vitro. 23(4):634-9. 
17. Miyake JA. (2009) Gamma-linolenic acid inhibits both tumour cell cycle progression and angiogenesis in the orthotopic C6 glioma model through changes in VEGF, Flt1, ERK1/2, MMP2, cyclin D1, pRb, p53 and p27 protein expression. Lipids Health Dis. 8:8.

18. Wakai K., Okamoto K., Tamakoshi A., Lin Y., Nakayama T., and Ohno Y. (2001) Seasonal allergic rhinoconjunctivitis and fatty acid intake: a cross-sectional study in Japan. Ann Epidemiol. 11(1):59-64.

19. Worm M., and Henz BM. (2000) Novel unconventional therapeutic approaches to atopic eczema. Dermatology. 201(3):191-195.

20. Gordon C., Shore V., and Jean V. (2005) Modulating the Bcl-2 Family of Apoptosis Suppressors for Potential Therapeutic Benefit in Cancer. Amer. Soc. Hematology. 226-230.

21. Nika N., and Danial. (2007) BCL-2 Family Proteins: Critical Checkpoints of Apoptotic Cell Death. Clin Cancer Res. 13(24): 7254-7263. 


\title{
THE EFFECT OF EXTRACTS ISOLATED FROM YOUNGIA TENUICAULIS IN LIVER CANCERCELL CULTURE
}

\author{
G. Nomintuya ${ }^{l}$, G. Odontuya ${ }^{2}$,Ts. Oyunsuren ${ }^{1}$ \\ ${ }^{\prime}$ Laboratory of Molecular Biology, MAS \\ ${ }^{2}$ Laboratory of Natural Product Chemistry, Institute of Chemistry and Chemical Technology, MAS
}

\begin{abstract}
Liver cancer of Hepatocellular carcinoma (HCC) is one of the most prevalent cancer which has being continuously increased during last decades among the population of Mongolia. Thus prevention, early diagnosis as well as treatment are important issue in our country.

The aim of present study was to find effects of 4 kinds of extracts isolated from Youngia tenuicaulis Babc. et Stebbings Czer., Compositae for cell and gene expression functions of HCC in vitro cell culture (PCC).

In our study, we cultured the primary cell culture (PCC) which has been established from HCC in our laboratory and cells were treated by different concentrations of Dichloromethane, Ethanol extracts isolated from $Y$. tenuicaulis.

The results of our study indicated that dichloromethane extract reduces the viability of HCC primary cell in dose dependent manner and cell migration was decreased by $86.6 \%$ compare to other extracts. The gene expression results showed that dichloromethane extract downregulates ZPYVE 1 and GPR 175 genes in mRNA level.

Our findings suggest that dichloromethane extract derived from Y. tenuicaulis, suppresses the focal adhesion site of cell function and can be use further experiments.
\end{abstract}

Key words: Youngia tenuicaulis, cancer cell, cell proliferation, gene expression 